\title{
Benefits of formal voluntary work among older people. A review
}

\author{
Mikaela B. von Bonsdorff ${ }^{1,2,3}$ and Taina Rantanen ${ }^{1}$ \\ ${ }^{1}$ Gerontology Research Centre, Dept. of Health Sciences, University of Jyväskylä, ${ }^{2}$ GeroCenter Foundation \\ for Research and Development, Jyväskylä, ${ }^{3}$ The Central Finland Health Care District, Jyväskylä, Finland
}

\begin{abstract}
Background and aims: A narrative review of quantitative population-based longitudinal studies was conducted to examine the association of formal voluntary work and personal well-being among older people doing the voluntary work and those being served. Methods: To be included, the study had to be published in a peer-reviewed journal, written in English and conducted in Western countries, participants were at least 60 years of age, the study employed a longitudinal or experimental design, the methodology and outcomes were explicitly described, and voluntary work quantified as visits or hours within a certain time frame. Results: Sixteen studies out of 2897 met the inclusion criteria for the review reporting on benefits of volunteering for those doing the voluntary work. Outcomes were collapsed into three categories of personal well-being: physical health, mental health, and psychosocial resources. All included studies came from the United States and showed that volunteering in old age predicted better self-rated health, functioning, physical activity and life satisfaction as well as decreased depression and mortality. However, it did not decrease the risk of chronic diseases or nursing home admission in old age. Only one study which met the inclusion criteria on the benefits of volunteering for older recipients was identified. Conclusions: Studies mainly used data from large datasets with only limited information about volunteering, which limits more detailed analyses. Randomized controlled trials are needed to study the effect of voluntary work on those being served, as well as to reveal the healthy participant effect among volunteers.
\end{abstract}

(Aging Clin Exp Res 2011; 23: 162-169)

${ }^{\circ}$ 2011, Editrice Kurtis

\section{INTRODUCTION}

Volunteering is defined as an activity which involves spending time, unpaid, doing something that aims to benefit the community in general, its individuals, or specified subsets of community members who are in need, such as older house-bound persons $(1,2)$. This review focused on formal volunteering and excluded informal volunteering such as helping and caring for close relatives, friends or neighbors. What differentiates formal and informal volunteering is a sense of obligation which is often stronger in informal volunteering than in formal volunteering, where volunteering depends more on the ability and opportunity of the helper (1). Volunteering has been quantified according to its intensity (amount of time spent), diversity (how many organizations) and consistency (how regularly the individual volunteers across the lifespan). Formal volunteering is usually coordinated by public agencies, non-profit agencies and religious organizations, or through government programs covering a wide range of activities $(1,3)$. Volunteering typically includes activities such as tutoring or mentoring, either instrumental, supportive or non-skilled; skilled or unskilled assistance or technical advice and public safety (4).

The increase in the older population in the $21^{\text {st }}$ century will be a challenge to public economies and healthcare service systems, but it may also offer possibilities. The predicted shortage in the labor force will increase the demand for volunteers in the future. The healthy active older population who are not engaged in paid work constitutes a growing reservoir of human and social capital (5-7), and volunteering is potentially a good venue to contribute to society (8). The generation born between 1946 and 1960 will enter old age with a great deal of experience and skills which may be transferred to the non-profit sector. In addition, increasing longevity, health and wealth

Key words: Formal volunteering, health, older people, post-retirement, well-being.

Correspondence: Mikaela von Bonsdorff, PhD, Gerontology Research Centre, Department of Health Sciences, University of Jyväskylä, PO Box 35 (Viveca), FIN-40014 University of Jyväskylä. E-mail: mikaela.vonbonsdorff@jyu.fi

Received March 10, 2010; accepted in revised form June 17, 2010. First published ahead of print July 16, 2010 as DOI: 10.3275/7200

Aging Clin Exp Res, Vol. 23, No. 3162 
allows for non-profit activities such as volunteering in later life $(9,10)$. Volunteering could be a cornerstone of productive aging, as it helps provide services of economic and social value $(11,12)$.

Most studies on volunteering have been done in the United States, which is the most active nation in volunteer work in Western countries. According to the Current Population Survey, the rate of volunteering in the US among people aged 65 years or over was $23.5 \%$ in 2008 (13). The long-standing tradition of volunteering in the US is partly due to the welfare system which, for example, builds on non-profit and religious organizations, as well as the fact that US policy-makers have actively encouraged volunteering (14). In Europe, the rate of volunteering differs among countries, depending on welfare policy (15). In Nordic countries, where the public healthcare system is responsible for social welfare, older people participate more actively in voluntary work than in Mediterranean countries. There, interfamily exchange is strong and cohabitation among generations more usual than in Northern Europe (16). Cross-national data from the Survey of Health, Ageing and Retirement in Europe (SHARE) on volunteering showed that the rate of volunteering ranged between 2 and $21 \%$, with an average of $10 \%$, depending strongly on the countries' societal context concerning volunteering (17). In Australia about $20 \%$ (18) and in Canada about 18\% (19) of the older population had volunteered in the previous year.

The relationship between volunteering and well-being has been identified in cross-sectional studies (20-22). However, there is the problem of causal order between well-being and volunteering, which can only be addressed with a prospective study design (23). Good health and adequate social resources tend to increase the probability of doing volunteer work $(7,23-26)$. It has been argued that persons who are physically and mentally fit are not only able, but also likely to be equipped with personal resources, such as high self-esteem or control over their lives, which increase the likelihood of volunteering $(1,23$, $26)$. It is equally plausible that health determines volunteering, rather than the other way around. In addition, the curvilinear relationship between volunteering and well-being $(27,28)$ also shows that a moderate but not high number of hours spent doing voluntary work enhances late-life health and well-being.

Although a fairly large body of literature exists regarding the various benefits of volunteering for those doing such work, earlier reviews $(9,20,29,30)$ did not investigate the benefits of volunteering systematically, with clearly defined inclusion and exclusion criteria. The aim of this review was to conduct a systematized narrative literature review on quantitative data, to examine the association of formal voluntary work and personal well-being among older people doing voluntary work and those being served.

\section{METHODS}

\section{Search strategy}

We searched for relevant studies published in English until November 30, 2009, without a start date, using the following databases: PubMed, Cochrane Central Register of Controlled Trials, Cochrane Database for Systematic Reviews, CINAHL (Cumulative Index to Nursing and Allied Health Literature), ERIC (Education Resources Information Center), PsycINFO, Ovid MEDLINE, ISI Web of Knowledge, and CSA (Sociological Abstracts). Depending on the database, search terms included combinations of volunteering: "voluntary work"; aged; "older people"; volunteerism; "benefits of volunteering"; "people being served"; "quality of life"; intervention; trial. The reference lists of identified papers and reviews were also searched through for relevant articles. On the basis of their abstracts, we assessed whether the study had the potential to be included and, according to the full articles, decided whether the study met the inclusion criteria.

\section{Inclusion criteria}

The following inclusion criteria were used: a) the study was published in a peer-reviewed journal; b) it was written in English and conducted in Western countries; c) participants were at least 60 years of age; d) the study employed a longitudinal or experimental design; e) its methodology and outcomes were explicitly described; and f) voluntary work was quantified as visits or hours within a certain timeframe. Selection was made by the reviewer (M.v.B) and, in cases of uncertainty regarding study inclusion, the senior reviewer (T.R) was consulted.

\section{RESULTS}

2897 studies on older people volunteering were identified in the literature search, of which 16 were accepted for this review (see Fig. 1 for review flow). The main reasons for exclusion were that the study was cross-sectional, participants were under 60 years of age, volunteering was defined to include also informal volunteering, or the study had not been published in a peer-reviewed journal. The selected studies examined the associations of volunteering with the well-being of those who did the voluntary work. Thirteen observational studies analyzed data from large populationbased prospective datasets, and three experimental studies used data from one randomized controlled trial. All studies were conducted in the US. Studies which used the same large datasets were reviewed as separate studies when they investigated different outcomes.

\section{Prospective studies included in the review}

In the chosen population-based prospective studies, the number of participants ranged from 705 to 7496 , except for one which included 71 women from the Baltimore Experience Corps Extended Pilot Study, matched with a comparison cohort of 150 women from the Women's 


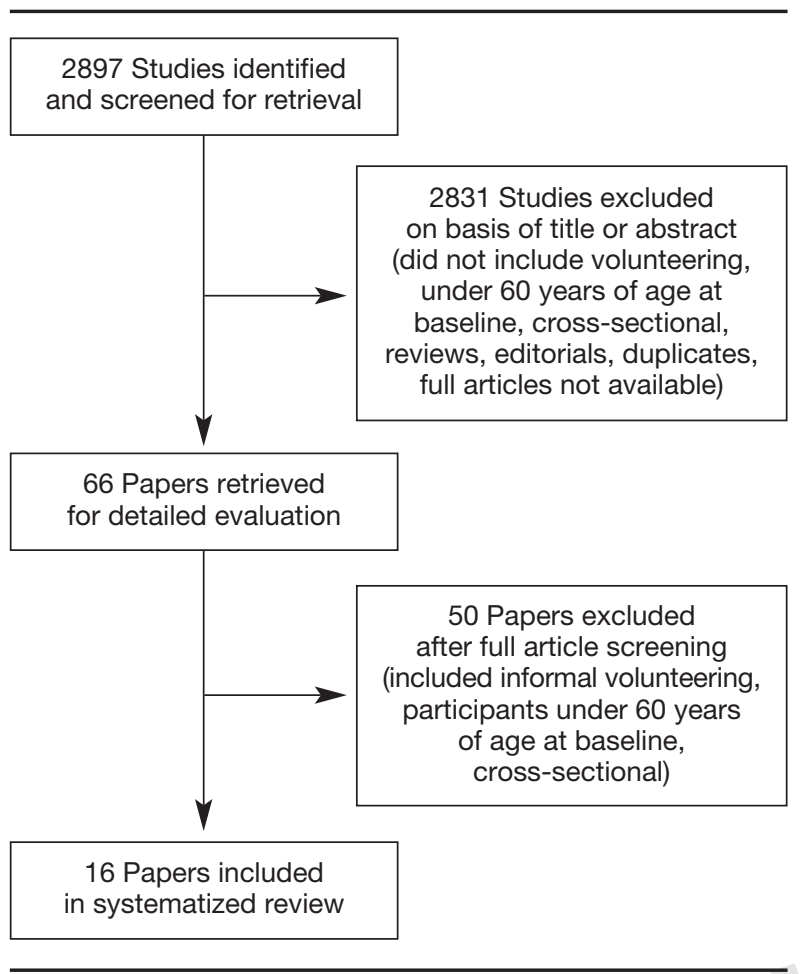

Fig. 1 - Literature review flow diagram.

Health and Aging Study (31) (for description of included studies, see Table 1). Age ranged between 60 and 97 years (mean age 70.1-77.0 yrs). Most of the participants (60$70 \%)$ were women and predominantly white. Volunteers were more highly educated, had better perceived health and fewer functional impairments than non-volunteers (28). However, most of the studies did not present baseline data according to voluntary status, making it hard to compare volunteers with non-volunteers as regards socio-demographics, health and functional status.

In the prospective datasets, voluntary work was mostly defined as the number of organizations the person volunteered for and the total amount of hours devoted to doing formal voluntary work during the previous 12 months. There was very little information on the nature and duration of the voluntary work or the setting where volunteering took place. Among persons 65 years and over, the volunteering rate in the previous year ranged between $12 \%$ and $34.5 \%$ in the population-based studies. The organizations for which participants had volunteered included churches or other religious organizations, schools or educational organizations, and political groups or unions. The average number of organizations that the volunteers worked for was 1.7 (32). The number of hours spent doing voluntary work ranged from 0 to 200. Among volunteers the average number of hours spent volunteering was 72-73 in the previous year (28,
32). Some studies $(10,27)$ reported the average hours spent volunteering throughout the study populations, which reflects the number of persons who actually volunteered rather than the amount of volunteering they did.

The large datasets such as ACL and LSOA, with several data collection waves over long surveillance periods, had relatively high attrition, due to non-response, not being able to contact participants, and deaths. Although missing data are often considered to be ubiquitous in longitudinal studies, this fact should be accounted for with current methods to avoid biased results (33). When dealing with missing data, it is important to ascertain whether it is missing at random or not at random, and where, in the latter case, systematic differences exist between missing and the observed values even after observed data are taken into account (34). Different imputation methods, such as multiple imputation, recommended for treating data which are missing at random, were used in some of the prospective studies on the ACL $(3,10,32)$ and LSOA data (35). Attrition in studies drawing on data from the AHEAD study was stated to have been small throughout the three data waves, and weights were used to compensate for it $(11,36)$.

Randomized controlled trials included in the review

The Experience Corps implemented in Baltimore, Maryland (6) is so far the only randomized controlled trial (RCT) on volunteering among older people. The RCT was designed to generate social benefits and simultaneously offer a community-based approach to health prevention. The 128 predominantly Afro-American participants were randomized into an intervention group or a control waiting list. The eligibility criteria for the trial were: 60 years or older; ability to read and pass a criminal background check; ability to travel to the schools; a Mini-Mental State Examination (37) score of 24 or above, and/or meeting a threshold score on the Trail Making Test (38). Participants in the intervention group served at least 15 hours per week in elementary schools, helped the children with their reading, gave them library support, and taught them classroom behavior over an academic year (39).

Longitudinal associations of volunteering and personal well-being

Outcomes were pooled together and collapsed into three categories of personal well-being: physical health, mental health, and psychosocial resources (23) (Table 2). Several studies found a non-linear relationship between volunteering and well-being (32), suggesting that a certain amount of involvement is optimal but that a lower level of volunteering is beneficial for well-being (27). MorrowHowell et al. demonstrated that about 100 hours per year yielded the greatest benefit of volunteering and that more hours per year did not increase the gains (32). There were only a few studies examining volunteering from the viewpoint of more than just the number of hours committed to 
Table 1 - Characteristics of prospective studies included in the review.

\begin{tabular}{|c|c|c|c|c|c|c|}
\hline Reference & Participants & Voluntary work & Confounders & Follow-up & Outcomes & Results \\
\hline $\begin{array}{l}\text { Harris and } \\
\text { Thoreson } 2005 \\
\text { (LSOA) }\end{array}$ & $\begin{array}{l}7496 \\
15.4 \% \\
\text { volunteered } \\
70+\text { yrs }\end{array}$ & $\begin{array}{l}\text { Never/rarely/sometime/ } \\
\text { frequently volunteers } \\
\text { during previous year }\end{array}$ & $\begin{array}{l}\text { Socio-demographics, } \\
\text { Health, Physical activity, } \\
\text { Social support }\end{array}$ & 8 yrs & Mortality & Reduced mortality \\
\hline $\begin{array}{l}\text { Hong S-I et al. } \\
2009 \text { (LSOA) }\end{array}$ & $\begin{array}{l}5294 \\
21.6 \% \\
\text { volunteered } \\
70+\text { yrs }\end{array}$ & $\begin{array}{l}\text { Yes/no during } \\
\text { previous year }\end{array}$ & $\begin{array}{l}\text { Socio-demographics, } \\
\text { Co-morbidities, } \\
\text { Self-rated health, } \\
\text { Functional limitation, } \\
\text { Functional dependency }\end{array}$ & 6 yrs & Depression & Decreased depression \\
\hline $\begin{array}{l}\mathrm{Li} \text { and Ferrano } \\
2005 \text { (ACL) }\end{array}$ & $\begin{array}{l}1669 \\
60+\text { yrs }\end{array}$ & $\begin{array}{l}\text { Volunteering } \\
\text { for 0-5 organizations, } \\
\text { hrs/in previous year }\end{array}$ & $\begin{array}{l}\text { Socio-demographics, } \\
\text { Church attendance, } \\
\text { Functioning, } \\
\text { Informal social integration }\end{array}$ & 8 yrs & Depression & Decreased depression \\
\hline $\begin{array}{l}\mathrm{Li} \text { and Ferrano } \\
2006 \text { (ACL) }\end{array}$ & $\begin{array}{l}1669 \\
60+\text { yrs } \\
87 \% \text { 45-59 yrs }\end{array}$ & $\begin{array}{l}\text { Volunteering } \\
\text { for 0-5 organizations, } \\
\text { hrs/past year }\end{array}$ & $\begin{array}{l}\text { Socio-demographics, } \\
\text { Church attendance, } \\
\text { Functioning, } \\
\text { Informal social integration }\end{array}$ & 8 yrs & $\begin{array}{l}\text { Functional } \\
\text { limitations }\end{array}$ & $\begin{array}{l}\text { Decreased depression and } \\
\text { reduced pace of functional } \\
\text { limitations }\end{array}$ \\
\hline $\begin{array}{l}\text { Lum and Lightfoot } \\
2005 \text { (AHEAD) }\end{array}$ & $\begin{array}{l}7322, \\
13 \% \\
\text { volunteered } \\
70+\text { yrs }\end{array}$ & $\begin{array}{l}0-99 \text { or } 100 \mathrm{hrs} \\
\text { or more work for } \\
\text { charitable/religious } \\
\text { organization/ } \\
\text { in previous year }\end{array}$ & Socio-demographics & 7 yrs & $\begin{array}{l}\text { Self-reported health, } \\
\text { Medical conditions, } \\
\text { Depression level, } \\
\text { Functioning level, } \\
\text { Nursing home entry, } \\
\text { Mortality }\end{array}$ & $\begin{array}{l}\text { Decreased depression, } \\
\text { reduced loss of function- } \\
\text { ing, not associated with } \\
\text { medical conditions or } \\
\text { nursing home entry }\end{array}$ \\
\hline $\begin{array}{l}\text { Luoh and Herzog } \\
2002 \text { (AHEAD) }\end{array}$ & $\begin{array}{l}4860 \\
12 \% \\
\text { volunteered } \\
\geq 100 \text { hrs } \\
70+\text { yrs }\end{array}$ & $\begin{array}{l}0-99 \text { or } 100 \mathrm{hrs} \\
\text { or more work for } \\
\text { charitable/religious } \\
\text { organization/ } \\
\text { in previous year }\end{array}$ & $\begin{array}{l}\text { Socio-demographics, } \\
\text { Physical activity, } \\
\text { Social contact, } \\
\text { Cognitive functioning, } \\
\text { Depressive symptoms }\end{array}$ & 2 yrs & $\begin{array}{l}\text { Self-reported health, } \\
\text { Functional status, } \\
\text { Mortality }\end{array}$ & $\begin{array}{l}\text { Volunteering } \geq 100 \mathrm{hrs} \\
\text { lowered risk of ill health, } \\
\text { daily living limitations } \\
\text { and mortality }\end{array}$ \\
\hline $\begin{array}{l}\text { Morrow-Howell et al. } \\
2003 \text { (ACL) }\end{array}$ & $\begin{array}{l}1669 \\
34.5 \% \\
\text { volunteered } \\
60+\text { yrs }\end{array}$ & $\begin{array}{l}\text { Volunteering } \\
\text { for 0-5 organizations, } \\
\text { hrs/in previous year }\end{array}$ & $\begin{array}{l}\text { Socio-demographics, } \\
\text { Informal social integration }\end{array}$ & 8 yrs & $\begin{array}{l}\text { Functional } \\
\text { dependency, } \\
\text { Self-rated health, } \\
\text { Depression }\end{array}$ & $\begin{array}{l}\text { Reduced functional } \\
\text { dependency and depres- } \\
\text { sion, positively associated } \\
\text { with self-rated health }\end{array}$ \\
\hline $\begin{array}{l}\text { Musick et al. } \\
1999 \text { (ACL) }\end{array}$ & $\begin{array}{l}1211 \\
35 \% \\
\text { volunteered } \\
65+\text { yrs }\end{array}$ & $\begin{array}{l}\text { Volunteering } \\
\text { for } 0-5 \text { organizations, } \\
\text { hrs/in previous year }\end{array}$ & $\begin{array}{l}\text { Socio-demographics, } \\
\text { Health, Physical activity, } \\
\text { Informal social integration }\end{array}$ & 7.5 yrs & Mortality & $\begin{array}{l}\text { Volunteering decreased } \\
\text { mortality, curvilinear } \\
\text { association according to } \\
\text { number of hours volunteerec }\end{array}$ \\
\hline $\begin{array}{l}\text { Musick and Wilson } \\
\text { (2003) ACL }\end{array}$ & $\begin{array}{l}2348, \\
24-90 \text { yrs } \\
\text { (for the no. } \\
\text { of } 65 \text { +yrs no } \\
\text { data available) }\end{array}$ & $\begin{array}{l}\text { Volunteering } \\
\text { for } 0-5 \text { organizations, } \\
\text { Secular/religious } \\
\text { work, periods of } \\
\text { volunteering } 1-3\end{array}$ & $\begin{array}{l}\text { Socio-demographics, } \\
\text { Social resources, } \\
\text { Psychological resources, } \\
\text { Health and functioning, } \\
\text { Physical activity, } \\
\text { Church attendance }\end{array}$ & 8 yrs & Depression & Decreased depression \\
\hline $\begin{array}{l}\text { Sabin } 1993 \\
\text { (LSOA) }\end{array}$ & $\begin{array}{l}7485 \\
15.6 \% \\
\text { volunteered } \\
70+\text { yrs }\end{array}$ & $\begin{array}{l}\text { Yes/no } \\
\text { in previous year }\end{array}$ & $\begin{array}{l}\text { Socio-demographics, } \\
\text { Self-rated health, } \\
\text { Functional dependency }\end{array}$ & 4 yrs & Mortality & Reduced mortality \\
\hline $\begin{array}{l}\text { Tan et al. } 2009 \\
\text { (EC, WHAS) }\end{array}$ & $\begin{array}{l}60+\text { yrs } \\
\text { EC=71 } \\
\text { WHAS=150 } \\
\text { African } \\
\text { American } \\
\text { women }\end{array}$ & $\begin{array}{l}\geq 15 \mathrm{~h} / \text { week for } \\
\text { an academic year in } \\
\text { an elementary school }\end{array}$ & $\begin{array}{l}\text { Socio-demographics, } \\
\text { Health, Mobility disability, } \\
\text { Frailty category }\end{array}$ & 3 yrs & Physical activity & $\begin{array}{l}\text { Volunteering increased } \\
\text { level of physical activity } \\
\text { compared with controls }\end{array}$ \\
\hline $\begin{array}{l}\text { Tan } 2009 \\
\text { (ACL) }\end{array}$ & $\begin{array}{l}1669 \\
34.5 \% \\
\text { volunteered } \\
60+\text { yrs }\end{array}$ & $\begin{array}{l}\text { Volunteering } \\
\text { for 0-5 organizations, } \\
\text { hrs/in previous year }\end{array}$ & $\begin{array}{l}\text { Socio-demographics, } \\
\text { Informal social contact }\end{array}$ & 8 yrs & $\begin{array}{l}\text { Self-rated health, } \\
\text { Functional } \\
\text { dependency, } \\
\text { Chronic diseases }\end{array}$ & $\begin{array}{l}\text { Volunteering associated } \\
\text { with improved self-rated } \\
\text { health, decreased functional } \\
\text { dependency, but not } \\
\text { with diseases }\end{array}$ \\
\hline $\begin{array}{l}\text { Van Willigen } \\
2000 \text { (ACL) }\end{array}$ & $\begin{array}{l}705, \\
39 \% \\
\text { volunteered } \\
60+\text { yrs }\end{array}$ & $\begin{array}{l}\text { Volunteering } \\
\text { for 0-5 organizations, } \\
\text { hrs/in previous year }\end{array}$ & $\begin{array}{l}\text { Socio-demographics, } \\
\text { Social integration, } \\
\text { Social support }\end{array}$ & 3 yrs & $\begin{array}{l}\text { Life satisfaction, } \\
\text { Self-rated health }\end{array}$ & $\begin{array}{l}\text { Volunteering was } \\
\text { positively associated } \\
\text { with both outcomes }\end{array}$ \\
\hline
\end{tabular}

ACL: American's Changing Lives, AHEAD: Asset and Health Dynamics Among the Oldest Old Study, EC: Baltimore Experience Corps, LSOA: The Longitudinal Study on Aging, WHAS: Women's Health and Aging Studies. M=mean, SES=socio-economic status.

165 Aging Clin Exp Res, Vol. 23, No. 3 
it. Building on ACL data, Morrow-Howell et al. reported that the number and type of organization coordinating the voluntary work was not associated with well-being outcomes (32). However, in another study using the same data, Musick et al. showed that the risk for death was lower for those who volunteered for one organization (27) and Musick and Wilson showed a few years later that religious volunteering and the longer duration of volunteering predicted better well-being in older age (3).

Most prospective studies examined the relationship between volunteering and physical health. A series of studies found that volunteering predicted better self-rated health. Using the AHEAD data, Luoh and Herzog showed that those who had volunteered 100 hours or more during the previous year rated their health better than those who had volunteered fewer hours (36). Conversely, two studies $(10,11)$, drawing on data from AHEAD and ACL, reported no association between volunteering and the number of self-reported physician-diagnosed chronic diseases. In all studies, volunteering at the age of 60 years or later predicted fewer difficulties or disability in activities of daily living tasks than among non-volunteers, with follow-ups ranging from 2 to 8 years $(10,11,32,36,40)$. Tang used ACL 1 through three data waves to show that increased hours spent volunteering at the age of 60 years or later predicted lower levels of functional dependency (10). Lum and Lightfoot found, using the AHEAD data, that volunteering was not associated with living in a

Table 2 - Personal well-being framework.

\begin{tabular}{|c|c|c|}
\hline Personal well-being & Measure & Reference \\
\hline \multicolumn{3}{|l|}{ I. Physical health } \\
\hline Morbidity & Physician-diagnosed chronic diseases & $\begin{array}{l}\text { Lum and Lightfoot } 2005 \\
\text { Tan } 2009\end{array}$ \\
\hline Self-rated health & Self-report, 5 categories & $\begin{array}{l}\text { Van Willigen } 2000 \\
\text { Luoh and Herzog } 2002 \\
\text { Morrow-Howell et al. } 2003 \\
\text { Lum and Lightfoot } 2005 \\
\text { Tan } 2009\end{array}$ \\
\hline Functional status & ADL and IADL disability & $\begin{array}{l}\text { Luoh and Herzog } 2002 \\
\text { Morrow-Howell et al. } 2003 \\
\text { Fried et al. 2004 } \\
\text { Lum and Lightfoot } 2005 \\
\text { Li and Ferrano } 2006 \\
\text { Tan } 2009\end{array}$ \\
\hline Physical activity & $\begin{array}{l}\text { Minnesota Leisure Time } \\
\text { Physical Activity } \\
\text { Questionnaire (MLTPAQ) } \\
\text { Self-reported physical activity questions } \\
\text { Strength*, endurance*, balance*, } \\
\text { physical tasks* }\end{array}$ & $\begin{array}{l}\text { Fried et al. } 2004^{*} \\
\text { Tan et al. } 2006 \\
\text { Tan et al. } 2009\end{array}$ \\
\hline Nursing home admission & Verified at follow-up data collection & Lum and Lightfoot 2005 \\
\hline Mortality & $\begin{array}{l}\text { Date of death; } \\
\text { National Death Index }\end{array}$ & $\begin{array}{l}\text { Sabin } 1993 \\
\text { Musick et al. 1999 } \\
\text { Luoh and Herzog } 2002 \\
\text { Harris and Thoreson } 2005^{\dagger} \\
\text { Lum and Lightfoot } 2005\end{array}$ \\
\hline \multicolumn{3}{|l|}{ II. Mental health } \\
\hline Depression & $\begin{array}{l}\text { CES-D score; } \\
\text { Self-reported single question }{ }^{\ddagger}\end{array}$ & $\begin{array}{l}\text { Lum and Lightfoot } 2005 \\
\text { Musick and Wilson } 2003 \\
\text { Morrow-Howell et al. } 2003 \\
\text { Li and Ferrano } 2005 \\
\text { Li and Ferrano } 2006 \\
\text { Hong et al. 2009 }\end{array}$ \\
\hline $\begin{array}{l}\text { Memory; } \\
\text { Executive functioning; } \\
\text { Psychomotor speed }\end{array}$ & $\begin{array}{l}\text { TMT, Rey-Osterrieth CFT; } \\
\text { Word lists }\end{array}$ & Carlson et al. 2008 \\
\hline Cognitive activity & Standardized questionnaire, self-report & Fried et al. 2004 \\
\hline \multicolumn{3}{|l|}{ III. Psychosocial resources } \\
\hline Life-satisfaction & Self-reported, 5 categories & Van Willigen 2000 \\
\hline
\end{tabular}

ADL: Activities of Daily Living; IADL: Instrumental Activities of Daily Living; CES-D: Center for Epidemiologic Studies Depression (49); TMT: Trail Making Test; Rey-Osterrieth CTF: Rey-Osterrieth Complex Figure Test. 
nursing home at the 7-year follow-up (11). Conversely, volunteering at the age of 60 years or later predicted lower mortality in prospective studies drawing on data from the ACL, AHEAD and LSOA studies (11, 27, 36, 41, 42).

Mental health and psychosocial resources are less frequently studied outcomes of volunteering among persons over 60 years of age, the focus being mainly on the association of volunteering and depression $(3,11,26,32$, $35,40)$. Building on three-wave data from the ACL study, Li and Ferrano found a beneficial effect of volunteering on depression during the 8-year follow-up (26). However, they also found evidence of certain self-selection processes while persons with higher socioeconomic status and active church attendees had a lower incidence of depression and were more actively engaged in volunteering (26). Drawing on data from ACL waves 1 and 2 , van Willigen showed that voluntary work increased life satisfaction among people over 60 years of age (28).

In a prospective study, Tan et al. compared the 71 women from the Experience Corps Pilot study, who did high-intensity voluntary work, with 150 non-volunteering women controls from the Women's Health and Aging Study, with a 3-year follow-up time (31). The non-volunteering women were aged 65-86 years and had comparable socio-economic status, self-rated health and frailty status. The study showed that the women who had volunteered in the high-intensity senior service program reported sustained increase in their physical activity level compared with their non-volunteering counterparts during the 3-year follow-up (31).

\section{Effects of volunteering on personal well-being}

Three papers examined the effect of high-intensity volunteering on physical functioning (39), physical activity $(39,43)$ and cognition $(39,44)$ in randomized controlled settings. The studies showed a positive trend in the effect of volunteering on cognitive and physical functioning, although the power in the analysis was limited. The intervention increased the overall physical activity level in the intervention group (39). In addition, when measured in kilocalories per week, the short-term increase in physical activity was significant among the Experience Corps volunteers compared with controls (43).

\section{Benefits of volunteering for those being served}

The benefits of volunteering for those being served could not be reviewed, because only one study which met the inclusion criteria was identified in the literature search. In that study, frail home-bound older persons participated in the Strong for Life exercise program, delivered by volunteers who had been trained by physical therapists for the task. After the 4-month program, the frail participants showed significant improvements on the Short Form-20 social functioning scale, although there were no significant differences in physical functioning, mental health or self-rat- ed health (45). The study did not include a control group so that the effect of the program could not be evaluated in a controlled setting. The basic idea of the study was to examine whether an exercise program such as Strong for Life could be feasibly, efficiently and safely delivered by specifically trained volunteers in voluntary organizations.

\section{DISCUSSION}

We identified and critically reviewed 16 studies examining whether volunteering predicted personal well-being among older people doing voluntary work. These studies used data from three population-based prospective datasets and one randomized controlled trial. Volunteering in old age predicted better self-rated health, functioning, physical activity and life satisfaction, as well as decreased depression and mortality. However, it did not decrease the risk of chronic diseases or nursing home admission in old age.

Possible mechanisms for the effect of volunteering on well-being have not been extensively discussed in the literature. The most common explanation is the beneficial association of the social contacts which develop during volunteering or more general social activities. It has been shown that social contacts and support have an effect on health and survival among older people and that volunteering fosters such connections $(36,42)$. Volunteering does involve a certain amount of physical and mental effort and these beneficial physiological effects probably contribute to the decreased risk of adverse health outcomes. Volunteering is also known to support psychological well-being, sense of control, and self-efficacy, which is positively related to health (23). This may also partly explain the curvilinear beneficial effect of volunteering seen in several studies $(27,36)$, in that reasonable amounts of volunteering are salubrious, but excessive amounts are less likely to enhance health. Little empirical work has been done on specific outcomes of volunteering $(4,32)$ or on the effect of different types of voluntary work on health (27, 42 ). Findings on the association of the number of organizations one volunteers for and subsequent well-being have been inconsistent $(3,27,32)$. Thus, in order to understand and examine the mechanisms underlying the positive association of volunteering, more detailed information on the nature of the voluntary work is needed.

The problem of causal order between well-being and volunteering is a challenging one. Nor can we completely control for the "healthy participant effect". It is a fact that people who are in good health and possess adequate social and economic resources tend to volunteer more $(23,26,27)$. They are also likely to be equipped with personal resources, such as high self-esteem or control over their lives, which increases the likelihood of volunteering $(23,26)$. Moen et al. showed in their prospective study that women who volunteered in 1956 were more likely to occupy multiple roles 30 years later and to have better health outcomes than those who did 
not volunteer earlier in their lives (46). That study differs from others comparing volunteering and its benefits across different age groups, like that of van Willigen (28), in that the period and cohort effect was controlled for. Volunteering presumably has a different meaning for people in different age groups born in different time periods and, in addition, there are underlying cultural norms and traditions which affect attitudes toward volunteering.

\section{Future implications for practice}

Volunteering is collectively seen as a feasible and humane way of helping people who cannot cope on their own, and as a potential field of productive activity for older fit retired persons who still have a lot to offer. The basic element underlying voluntary work is that it is a social activity which generates a considerable amount of social capital, not only to the receiver but also to the giver, and consequently also to society $(9,12)$. To date, people who retire have better health than ever before and they are expected to live longer without disabilities. Thus, they have extra time on their hands and, in some cases, their children and immediate family live further away and they do not help their own families on a day-to-day basis.

However, to what extent can older people be expected to be a productive part of the society? The sheer increase in leisure time after retirement cannot be assumed to result in more voluntary work being done (12). It is potentially harmful for social cohesion to label those who do not, for some reason, volunteer as unproductive in society (47). Older age increases the risk of debilitating illnesses and functional decline which hinders such activities, even though the person may wish to participate productively in society.

Some people, who are near retirement age lead extremely active lives and are often very committed to their working careers. They are likely to transfer some of their energy and the ambitious attitudes which they adopted during their paid working lives to post-retirement volunteering, which will probably result in changes in the current voluntary work policy. Volunteering could serve as a good extension to an active working career by offering mental and physical challenges and social contacts which would otherwise cease when the person retires (36). However, it remains to be seen whether the baby-boomers will engage more actively in voluntary work than the older retired population today.

Although volunteering is a charitable activity, we should bear in mind that it opens the doors of vulnerable older persons who do not necessarily understand the potential dangers and who may thus end up as targets for abuse (48). This is why it is crucial for voluntary work to be coordinated and monitored by responsible organizations with unified standards for voluntary work. The people who do 'hands-on' voluntary work need to be properly trained for the task. Volunteering should be evaluated rigorously, and there should be clearly defined quality criteria for its implementation.

\section{Future implications for research}

There are only a few large datasets in the world that have been used for studying volunteering among older people. Most research data on the associations and effects of volunteering on health and well-being come from the United States and may not be applicable to European countries. In addition, the limited information available on the history of volunteer work in earlier life as well as the frequency and duration of volunteering in the large datasets limit more detailed analysis of this activity (3). Selection and social causation poses further challenges to determining the effect of volunteer work on well-being (23). For example, it is challenging to recruit people for volunteering studies who do not usually participate in any studies, e.g. those who come from diverse socio-economic backgrounds and who have few social contacts, but who potentially stand to benefit from social activities such as volunteering. Another potential threat to analysis is attrition, which is considerable in a prospective large dataset such as ACL (32). In longitudinal studies on older people, attrition tends to be missing not at random, and those who drop out differ in earlier followups from those who responded. Attrition should be identified, described and dealt with in a proper way in prospective analyses (26). The effect of volunteering for those being served could be explored among people who live in similar settings with similar services and needs. For this purpose, randomized controlled trials are needed to determine the effect of volunteering on older people. To examine in greater depth the effect of volunteering for those doing the voluntary work, prospective observational studies, preferably starting in young life, are needed. In addition, gender and social class effects should be addressed more specifically, and life-time engagement in religious and social activities through social networks should be investigated in relation to voluntary work.

\section{CONCLUSIONS}

Volunteering has been shown to be positively associated with well-being in old age among those doing the voluntary work. However, it is not clear whether activities such as volunteering contribute to the health of older people, as opposed to healthy people being more likely to be engaged in volunteer activities. In addition, the mechanisms underlying the association between volunteering and well-being in old age have been poorly identified. To date, we know little about the effects of volunteering for those receiving help. Studies have predominantly used data from large datasets with only limited information about volunteering which prohibits more detailed analyses. Randomized controlled trials are needed to study the effect of voluntary work for those being served, as well as to reveal the healthy participator effect among volunteers. 


\section{REFERENCES}

1. Wilson J, Musick MA. Who cares? Toward an integrated theory of volunteer work. Am Sociol Rev 1997; 62: 694-713.

2. Davis Smith J. Civic service in Western Europe. Nonprof Volunt Sec Q 2004; 33: 64S-78S.

3. Musick MA, Wilson J. Volunteering and depression: The role of psychological and social resources in different age groups. Soc Sci Med 2003; 56: 259-69.

4. Morrow-Howell N, Hong SI, Tang F. Who benefits from volunteering? Variations in perceived benefits. Gerontologist 2009; 49: 91-102.

5. Moen P, Fields V. Midcourse in the United States: Does unpaid community participation replace paid work? Ageing Int 2002; 27: 2148.

6. Glass TA, Freedman M, Carlson MC et al. Design of an intergenerational program to boost social capital and promote the health of an aging society. J Urban Health 2004; 81: 94-105.

7. Choi NG, Burr JA, Mutchler JE, Caro FG. Formal and informal volunteer activity and spousal caregiving among older adults. Res Aging 2007; 29: 99-124.

8. Butler RN. The study of productive aging. J Gerontol B Psychol Sci Soc Sci 2002; 57: S323

9. Gottlieb BH, Gillespie AA. Volunteerism, health, and civic engagement among older adults. Can J Aging 2008; 27: 399-406.

10. Tang F. Late-life volunteering and trajectories of physical health. J Appl Gerontol 2009; 28: 524-33.

11. Lum $T$, Lightfoot $\mathrm{E}$. The effects of volunteering of the physical and mental health of older people. Res Aging 2005; 27: 31-55.

12. Rozario PA. Volunteering among current cohorts of older adults and baby boomers. Generations 2006; 29: 31-6.

13. United States Department of Labor. Volunteering in the United States, 2008. United States Department of Labor, 2009.

14. Baldock CV. Seniors as volunteers: an international perspective on policy. Ageing Soc 1999; 19: 581-602.

15. Esping-Andersen G. The Three Worlds of Welfare Capitalism. Princeton, NJ: Princeton University Press, 1990.

16. Hank K, Erlinghagen M. Dynamics of volunteering in older Europeans. Gerontologist 2010; 50: 170-8.

17. Erlinghagen M, Hank K. The participation of older Europeans in volunteer work. Ageing Soc 2006; 26: 567-84.

18. Australian Bureau of Statistics. Voluntary Work, Australia 2006, catalogue no. 4441.0. Canberra: ABS; 2007.

19. Lasby D, Mclver D. Where Canadians volunteer: volunteering by type of organization. Toronto, Ontario: Canadian Centre for Philanthropy, 2004.

20. Wheeler JA, Gorey KM, Greenblatt B. The beneficial effects of volunteering for older volunteers and the people they serve: a meta-analysis. Int J Aging Hum Dev 1998; 47: 69-79.

21. Greenfield EA, Marks NF. Formal volunteering as a protective factor for older adults' psychological well-being. J Gerontol B Psychol Sci Soc Sci 2004; 59: S258-64.

22. Windsor TD, Anstey KJ, Rodgers B. Volunteering and psychological well-being among young-old adults: how much is too much? Gerontologist 2008; 48: 59-70.

23. Thoits P, Hewitt L. Volunteer work and well-being. J Health Soc Behav 2001; 42: 115-31.

24. Warburton J, Le Brocque R, Rosenman L. Older people - the reserve army of volunteers? an analysis of volunteerism among older Australians. Int J Aging Hum Dev 1998; 46: 229-45.

25. Musick MA, Wilson J, Bynum WB. Race and formal volunteering: the differential effects of class and religion. Social Forces 2000; 78 1539-71.

26. Li Y, Ferrano K. Volunteering and depression in later life: social benefit or selection processes? J Health Soc Behav 2005; 46: 68-84.
27. Musick MA, Herzog AR, House JS. Volunteering and mortality among older adults: findings from a national sample. J Gerontol B Psychol Sci Soc Sci 1999; 54: S173-80.

28. Van Willigen M. Differential benefits of volunteering across the life course. J Gerontol B Psychol Sci Soc Sci 2000; 55: S308-18.

29. Onyx J, Warburton J. Volunteering and health among older people: A review. Australas J Ageing 2003; 22: 65-9.

30. Corporation for National \& Community Service, Office of Research and Policy Development. The health benefits of volunteering: a review of recent research. Washington, DC: Corporation for National \& Community Service, 2007

31. Tan EJ, Rebok GW, Yu Q et al. The long-term relationship between high-intensity volunteering and physical activity in older African American women. J Gerontol B Psychol Sci Soc Sci 2009; 64: 304-11

32. Morrow-Howell N, Hinterlong J, Rozario PA, Tang F. Effects of volunteering on the well-being of older adults. J Gerontol B Psychol Sci Soc Sci 2003; 58: S137-45.

33. Sterne JA, White IR, Carlin JB et al. Multiple imputation for missing data in epidemiological and clinical research: Potential and pitfalls. BMJ 2009; 338: b2393.

34. Graham JW. Missing data analysis: making it work in the real world. Annu Rev Psychol 2009; 60: 549-76.

35. Hong SI, Hasche L, Bowland S. Structural relationships between social activities and longitudinal trajectories of depression among older adults. Gerontologist 2009; 49: 1-11.

36. Luoh M, Herzog R. Individual consequences of volunteer and paid work in old age: Health and mortality. J Health Soc Behav 2002; 43: 490-509.

37. Folstein MF, Folstein SE, McHugh PR. "Mini-Mental State". A practical method for grading the cognitive state of patients for the clinician. J Psychiatr Res 1975; 12: 189-98.

38. Reitan R. Validity of the trail making test as an indicator of organic brain damage. Percept Motor Skill 1958; 8: 271-6.

39. Fried LP, Carlson MC, Freedman M et al. A social model for health promotion for an aging population: initial evidence on the Experience Corps model. J Urban Health 2004; 81: 64-78.

40. Li Y, Ferrano K. Volunteering in middle and later life: Is health a benefit, barrier or both? Soc Forces 2006; 85: 497-519.

41. Sabin E. Social relationships and mortality among the elderly. J Appl Gerontol 1993; 12: 44-60.

42. Harris AH, Thoresen CE. Volunteering is associated with delayed mortality in older people: Analysis of the longitudinal study of aging. J Health Psychol 2005; 10: 739-52.

43. Tan EJ, Xue QL, Li T, Carlson MC, Fried LP. Volunteering: A physical activity intervention for older adults - the Experience Corps Program in Baltimore. J Urban Health 2006; 83: 954-69.

44. Carlson MC, Saczynski JS, Rebok GW et al. Exploring the effects of an "everyday" activity program on executive function and memory in older adults: Experience Corps. Gerontologist 2008; 48: 793-801.

45. Etkin CD, Prohaska TR, Harris BA, Latham N, Jette A. Feasibility of implementing the Strong for Life Program in community settings. Gerontologist 2006; 46: 284-92.

46. Moen P, Dempster-McClain D, Williams M. Successful aging: A lifecourse perspective on women's multiple roles and health. Am J Sociol 1992; 97: 1612-38.

47. Hank K, Erlinghagen M. Volunteering in "old" Europe. J Appl Gerontol 2010; 39: 3-20.

48. Cooper C, Selwood A, Livingston G. The prevalence of elder abuse and neglect: a systematic review. Age Ageing 2008; 37: 151-60.

49. Radloff L. The CES-D scale: a self-report depression scale for research in the general population. Appl Psych Meas 1977; 1: 385-401. 